\title{
Temperamental Properties of Personality and its Importance in Organization of Sports Activity
}

\author{
Salikhov Timur Mansurovich \\ Master of Bukhara State University \\ Shoymardanova Mukhsina Rakhmatovna \\ Director of Bukhara School № 6
}

\begin{abstract}
Modern sport is also characterized by the fact that trainings and competitions take place against the background of significant emotional and mental loads, against the background of intense mental activity caused by the rapid pace of daily life, variety of external stimuli, etc.

Studies show that temperament significantly affects sports activity, determining first of all its dynamic side. Now, apparently, it can be said that types of nervous system and temperament are characterized by different ways of balancing the body with the environment. Temperament determines the character, dynamics, and often qualitative specificity of this adaptation activity - people with different temperament properties come to the same result in a peculiar way, sometimes with different degrees of time, power and energy.
\end{abstract}

Key words: personality, temperament, psychological characteristic of temperament types, temperament properties, sports activity, choleric, sanguine, phlegmatic, melancholic.

Success in sports, as in other types of human activity, depends on a number of conditions, including peculiarities of processes of education, upbringing, training, preparation for competitions. These processes should be built and implemented not only on the basis of general psycho-pedagogical patterns, but also taking into account specific, psychologically justified methods and techniques of pedagogical influence, methods of organization of activities adapted to individual properties of the nervous system and temperament of those engaged.

The importance of studying the problem of temperament is absolutely undeniable in connection with issues of sports pedagogy, psychology, theory and methodology of physical education and sports training. Development of this problem will contribute to scientific justification of individualization of processes of education, training, preparation and participation in competitions.

The mutual relationship of properties is also manifested in the fact that the qualitative characteristic of each individual property depends on all other properties inherent in a given type of temperament. For example, lack of support is known to depend on the strength of nerve processes and their balance. Instability, i.e. the prevalence of excitation force over braking force, is possible with different expressions of nervous system force. The lack of support of a 
person whose strong arousal prevails over equally strong braking is passionate rampant. The lack of support of a person whose weak excitement prevails over even weaker braking is hysterical instability.

Psychological characterization of temperament types. At present, the following main properties are taken into account for the psychological characteristic of temperament types:

1. Sensitivity. This property is judged by what is the least external force necessary for any mental response of a person. This includes the least physical force of the irritant necessary to create sensations (low threshold of sensations), the least degree of satisfaction of the need, causing joy or suffering in the person.

2. Reactivity. This property is characterized by the power with which people respond emotionally to external or internal influences (critical remark, offensive word, threat, sharp and unexpected sound). The brightest manifestations of reactivity are emotionality, impressiveness.

Activity. This property is expressed by the degree of human influence on the outside world, its ability to overcome obstacles in the implementation of the Goals. This includes targeting and perseverance in achieving the goal, focusing on long-term work, etc.

The ratio of reactivity to activity, i.e., on which human activity depends to a greater extent: on accidental external or internal circumstances (mood, desires) or on its goals, intentions, aspirations, beliefs.

Rate of reactions. It is determined by the rate of various mental reactions and processes (speed of movements, tempo of speech, resourceness, rate of memorization, speed of mind).

Plasticity - rigidity. This property is judged by how easily and flexibly a person adapts to external influences (plasticity) or, on the contrary, how inert and oblique his behavior, habits, judgements (rigidities) are.

7. Extraversion - an introversion. In determining this property, account is taken of: on what the reactions and activities of the person depend mainly - on external impressions arising at the moment (extroversion), or on images, perceptions and thoughts related to the past and the future (introversion).

Modern science does not yet have enough facts to fully characterize all types of temperament. However, in the psychological characteristic of the four traditional types of temperaments, a clear manifestation of these properties can be seen. 
Sanguine (based on a strong, balanced, mobile type of nervous system) favours sports that are associated with great mobility, activity, require courage. These individuals easily move from performing one kind of exercise to another, but are not sufficiently firm and focused, especially in one-of-a-kind (training) activities. When studying new exercises, they quickly grab the basis of the motion being studied, can perform it quite easily from the first attempt, but with errors; Do not like painstaking and long-term work to improve the technique of performing the exercise. Athletes of this type are quite workable, confident in themselves, sociable. Their sports results are stable and, as a rule, in competitions are higher than on trainings. Before the start such athletes are most often in a state of "combat readiness."

Choleric (strong, unbalanced, excitation-dominated, type of nervous system). The cholerictype athlete prefers highly emotional sports (basketball, sprint, jumping), intense and tempo movements. He willingly and with passion begins to engage in the chosen sport, but his enthusiasm quickly disappears. Such athletes are reluctant to perform long training work on strength and endurance, but are able to repeat a difficult and dangerous exercise multiple times if it has aroused interest. Their competitive results are not stable enough, there is a tendency to "pre-launch fever," which quite often does not allow them to fully realize their opportunities in competitions.

Phlegmatic (strong, balanced, inert type of nervous system). In sports this temperament manifests itself primarily in insufficient rapid development and conversion of motor skills, in slow reactions, in difficulties of switching from one activity to another. The skills and habits formed are characterized by great strength, conservativeness. Such athletes are very capable and resistant to external stimuli, give preference to non-fast, calm, uniform exercises, are prone to long-term and careful work of technique of individual exercises, painstaking work on development of any quality, etc. Not characterized by high sociability. As a rule, very persistent and persistent. Competitive results are stable. Before the start, they are most often on "alert."

Melancholic (weak type of nervous system). In sports activity melancholic is characterized by excessively high responsibility, highly developed muscle-motor sensitivity, thin tactical sensitivity, but insufficient performance and low resistance to external stimuli, high anxiety, generating uncertainty in the forces. These persons give preference to individual sports not connected with single combat and team wrestling, competitive results of them are unstable, as 
inherent high anxiety contributes to formation of a state of "starting apathy," which makes it difficult to achieve high results.

Thus, in each type of temperament, in each type of relationship of its properties there are such qualities which can significantly influence sports activity. Therefore it is necessary to know to what extent temperament favors and how much it prevents success at different levels of sports activity.

\title{
References
}

1. Asmolov A. G. Psikhologiia lichnosti. [Psychology of Personality] - M. 1990. - 367p.

2. Viatkin B.A. Rol' temperamenta v sportivnoi deiatel'nosti. [The role of temperament in sports activities.] - M.: Fizkul'tura i sport, 1978. - 134 p.

3. Krechmer E. Teoriia temperamentov. // Psikhologiia individual'nykh razlichii. Khrestomatiia. [Theory of temperaments. // Psychology of individual differences. An anthology] - M. 2000. - P. 19-24

4. Merlin V.S. Ocherk teorii temperamenta. [Essay on the theory of temperament.] - M., 1964. $-304 \mathrm{p}$.

5. Nebylitsyn V.D. Aktual'nye problemy differentsial'noi psikhofiziologii. // Psikhologiia individual'nykh razlichii. Khrestomatiia. [Actual problems of differential psychophysiology. // Psychology of individual differences. An anthology.] - M., 2000. - P. 667-677.

6. Il'in E.L. Psikhologiia fizicheskogo vospitaniia: uchebnik dlia institutov i fakul'tetov fizicheskoi kul'tury [Psychology of physical education: a textbook for institutes and faculties of physical education] / E.L. Il'in. - SPb.: publishing house RGPU im. A.I. Gertsena, 2000. $486 \mathrm{p}$.

Translation of the Title, Abstract and References to the Author's Language

\section{ТЕМПЕРАМЕНТАЛЬНЫЕ СВОЙСТВА ЛИЧНОСТИ И ЕЕ ЗНАЧЕНИЕ В ОРГАНИЗАЦИИ СПОРТИВНОЙ ДЕЯТЕЛЬНОСТИ}

\author{
Салихов Тимур Мансурович \\ Магистрант Бухарского государственного университета, \\ Шоймарданова Мухсина Рахматовна \\ Директор школь №6 г. Бухары
}

Аннотация: Современный спорт характеризуется также тем, что тренировки и соревнования проходят на фоне значительных эмоциональных и психических нагрузок, на фоне напряженной умственной деятельности, вызываемых стремительным темпом повседневной жизни, многообразием внешних раздражителей и т. п. 
Исследования показывают, что темперамент существенным образом влияет на спортивную деятельность, определяя прежде всего ее динамическую сторону. Сейчас, видимо, можно говорить о том, что типы нервной системы и темперамента характеризуются разными способами уравновешивания организма со средой. Темперамент определяет характер, динамику, а нередко и качественное своеобразие этой приспособительной деятельности - люди с различными свойствами темперамента приходят к одному и тому же результату своеобразным путем, порой с разной степенью затраты времени, сил и энергии.

Ключевые слова: личность, темперамент, психологическая характеристика типов темпераментов, свойства темперамента, спортивная деятельность, холерик, сангвиник, флегматик, меланхолик.

\section{References}

1. Асмолов А. Г. Психология личности. - М. 1990. - 367 с.

2. Вяткин Б.А. Роль темперамента в спортивной деятельности. - М.: Физкультура и спорт, 1978. - 134 с.

3. Кречмер Э. Теория темпераментов. // Психология индивидуальных различий. Хрестоматия. - М., 2000. - С.19-24

4. Мерлин В.С. Очерк теории темперамента. - М., 1964. - 304 с.

5. Небылицын В.Д. Актуальные проблемы дифференциальной психофизиологии. // Психология индивидуальных различий. Хрестоматия. - М., 2000. - 667-677.

6. Ильин Е.Л. Психология физического воспитания: учебник для институтов и факультетов физической культуры / Е.Л. Ильин. - СПб.: изд-во РГПУ им. А.И. Герцена, 2000. -486 c. 